\title{
Ellipsis
}

2021

\section{The Proper Way to Prepare the U.S. Flag}

Carmin Wong

Follow this and additional works at: https://scholarworks.uno.edu/ellipsis

\section{Recommended Citation}

Wong, Carmin (2021) "The Proper Way to Prepare the U.S. Flag," Ellipsis: Vol. 46, Article 13.

DOI: https://doi.org/10.46428/ejail.46.13

Available at: https://scholarworks.uno.edu/ellipsis/vol46/iss1/13

This Poetry is brought to you for free and open access by the Department of English and Foreign Languages at ScholarWorks@UNO. It has been accepted for inclusion in Ellipsis by an authorized editor of ScholarWorks@UNO. For more information, please contact scholarworks@uno.edu. 


\section{Vassar Miller Poetry Award, Honorable Mention}

\section{The Proper Way to Prepare the U.S. Flag by Carmin Wong}

Start with something simple: lines. 13 loosely lingering light-hearted lines. That eventually turns into crowbars; prison cells; laugh lines. Slave ships. Carve the middle out perfectly. Make its name into a noose. Mark its territory. Hang it on a shallow Cypress. Call it a show. Call everyone you know. Tie a mask around their necks. Sing of conquest conquest, conquest, conquest, conquest, conquest--- Call it savagery unity. Color over bloodlines. Color it blood until its red stains. Name it sacrifice. Silent. The Last Night. Jesus. Call it holy. Start with something simple: draw. 50 bullet holes into the formation of a third eye. A blinded country with a 20/20 vision of a white male as savior. Hold it against your heart and pray for your allegiance. Hold it against your chest and pray for democracy. Hold it up against a wall; a border; a blockade; watch it barbwire an entire world and strip the existence from right under you, leave you behind in star-spangled pieces. Call it diaspora. Dispersal. Dissipate the blackness from the bodies, the black away from the black body. Paint it across the back of a body. Wrangle it from bootstraps and watch it/ hang. 